\title{
Overweight, Obesity, Central Adiposity and Associated Chronic Diseases in Cuban Adults
}

\author{
María Elena Díaz, PhD, Santa Jiménez, MD, PhD, René Guillermo García, MD, MS, Mariano Bonet, MD, Iraida Wong, BS
}

\begin{abstract}
Introduction Prevalence of overweight and obesity is increasing worldwide in parallel with the growing burden of noncommunicable chronic diseases. According to the World Health Organization, in 2005 approximately 1.6 billion individuals aged $\geq 15$ years were overweight and at least 400 million were obese; by 2015 these figures will almost double. Central distribution of adiposity has also been associated with higher rates of cardiovascular diseases and other conditions.

Objective Determine the prevalence of overweight, obesity and central adiposity, and their association with noncommunicable chronic diseases and related lifestyle risk factors in Cuban adults.

Methods The Second National Survey on Risk Factors and Chronic Diseases (ENFRENT II), conducted in 2000-2001, surveyed a representative sample of males and females aged $\geq 15$ years using a stratified, multi-stage cluster sampling design. Data from a sub-sample of 19,519 individuals aged $\geq 20$ years were analyzed and prevalence calculated for diabetes, hypertension, cardiovascular and cerebrovascular diseases, and for each of these variables in association with overweight, obesity and central distribution of adiposity, and with the
\end{abstract}

presence of sedentary lifestyle, smoking, alcohol consumption, eating regular daily meals and daily breakfast.

Results Estimated prevalence of overweight and obesity in the adult population was $30.8 \%$ (Cl: $30.1-31.5)$ and $11.8 \%$ (Cl: $11.2-12.4)$, respectively. Obesity prevalence was twice as high in women $(15.4 \%$; Cl: $14.5-16.3)$ as in men (7.9\%; Cl: 7.3-8.6). Obesity was significantly more frequent in diabetics, hypertensives and people with heart disease, while central adiposity was significantly associated with a higher prevalence of diabetes mellitus, cardiovascular and cerebrovascular diseases, hypertension, obesity and overweight. Smoking and alcohol consumption were low among overweight and obese subjects, who exhibited a higher prevalence of irregular and inadequate eating patterns.

Conclusions Prevalence of overweight, obesity and central adiposity, and comorbidity with diabetes mellitus, hypertension and heart disease, are growing public health problems in Cuba. A multi-sector strategy is needed to develop comprehensive food and nutrition policies and programs aimed at halting these trends, including interventions that encourage healthy eating patterns and regular physical activity in adults and children.

Keywords: Overweight, obesity, comorbidity, chronic disease, prevalence, nutrition disorders

\section{INTRODUCTION}

Overweight and obesity constitute a looming public health problem affecting both industrialized and developing countries. According to the World Health Organization (WHO), in 2005, approximately 1.6 billion individuals aged $\geq 15$ years were overweight and at least 400 million were obese; these figures are expected to almost double by 2015.[1]

As obesity prevalence has risen in most of the world, there has also been an overall increase in comorbidity from noncommunicable chronic diseases,[1] particularly cardiovascular disease, the world's number one cause of death, killing 17 million people each year, and the leading cause of mortality in obese individuals.[2]

At the same time, diabetes mellitus has rapidly become a global epidemic; WHO projects that diabetes deaths will increase by more than $50 \%$ in the next 10 years.[1] In the United States, a survey of 33 states in two periods showed a $90 \%$ increase in age-adjusted incidence of diabetes, from 4.8 per 1000 population in 1995-1997 to 9.1 per 1000 population in 2005-2007. The data indicated that diabetes risk may be attributed to overweight. [3] A recent cross-sectional study reported a $40 \%$ prevalence of hypertension in US adults.[4]

While moderate weight gain may lead to unfavorable health outcomes in an individual, the rise in obesity is shortening life expectancy in populations.[1] Most studies show an increase in mortality rates associated with obesity, primarily due to cardiovascular causes.[2] Obese individuals have a $50-100 \%$ higher risk for all causes of morbidity and a life expectancy 2-5 years shorter than individuals with normal body weight. $[1,5]$ There is also evidence that obesity-related morbidity may increase the longer an individual is obese.[2]

Central distribution of adiposity is a risk factor for chronic disease independent of excess body weight. Comorbidity is often manifested through vascular and metabolic complications typically associated with abdominal or central obesity.[6] Unlike subcutaneous fat, abdominal fat is more metabolically active, more susceptible to hormonal stimulation and changes in lipid metabolism. In addition, high levels of abdominal fat cause a large influx of non-esterified free fatty acids to the liver through the portal vein.[7] This adiposity pattern (also known as android obesity) is so important that even a slight abdominal accumulation of adipose tissue has been associated with higher rates of cardiovascular disease and other conditions, including diabetes, hypertension, atherosclerosis, dyslipidemia and cholelithiasis. Cardiovascular risk associated with gynoid obesity (peripheral, lower or gluteo-femoral obesity) is comparatively lower.[1,7-11]

The objective of this study was to determine the prevalence of overweight, obesity and central distribution of adiposity, and their association with noncommunicable chronic diseases and certain lifestyle risk factors in Cuban adults.

\section{METHODS}

Data from the Second National Survey on Risk Factors and Chronic Diseases (ENFRENT II, its Spanish acronym) was used to calculate the prevalence of overweight, obesity and 
regional distribution of adipose tissue and their association with morbidity due to noncommunicable chronic diseases and lifestyle determinants.

The ENFRENT II study was conducted November 2000-March 2001 by the National Institute of Hygiene, Epidemiology and Microbiology (INHEM, its Spanish acronym), the National Statistics Bureau (ONE, its Spanish acronym), and the Nutrition and Food Hygiene Institute (INHA, its Spanish acronym).[12] All urban areas of the country were surveyed, and the results are representative nationally and by province. A complex, stratified, multi-stage cluster sampling design was used, based on the general sampling design developed by ONE in 1995 for the household survey system and updated in 1999.[13] Cuba's 14 provinces and the Isle of Youth Special Municipality served as the strata, while the clusters consisted of sampled geographic areas (SGA), blocks and sectors. A representative sample size was calculated for each stratum and provincial estimates were obtained. Prevalence was estimated for the national sample, the latter formed by aggregating the provincial samples and was therefore not equiprobable.

To compensate for differences in selection probability in the different subgroups, reduce bias due to reductions in sample size, obtain estimates of population totals and minimize shortcomings of the sampling frame (due to omitting households on the lists, for example), samples were weighted in inverse proportion to the probability of individual selection, considering sex and age.[13] Ultimately, 22,851 individuals aged $\geq 15$ years were surveyed. For the present study, data from the 19,519 respondents aged $\geq 20$ years, excluding pregnant women, were analyzed.

Informed consent was obtained from all ENFRENT II participants. Each person selected for the sample was given the option to refuse to participate or to interrupt the survey at any time. Participants found to have abnormal blood pressure or body mass index or any other abnormality were referred to their family doctor for care.

Overweight and obesity were defined and evaluated using Body Mass Index $\left[\mathrm{BMI}=\right.$ weight in $\left.\mathrm{kg} /(\text { height in } \mathrm{m})^{2}\right]$ and $\mathrm{WHO}$ cutoff points (BMI $25-29.9 \mathrm{~kg} / \mathrm{m}^{2}$ for overweight; $\mathrm{BMI} \geq 30 \mathrm{~kg} / \mathrm{m}^{2}$ for obesity).[14] Regional distribution of adipose tissue was determined by waist-to-hip ratio and risk levels for chronic disease set according to Seidell et al: low (men: $\leq 0.94$; women: $\leq 0.78$ ), intermediate (men: 0.95-0.99; women: 0.79-0.84) and high (men: $\geq 1.00$; women: $\geq 0.85)$.[8]

Self-reported data on morbidity and lifestyle determinants were obtained in structured interviews conducted in respondents' homes by professional interviewers trained by the research team. This information was used to develop survey variables[12] according to the following criteria:

- Diabetes mellitus-WHO International Diabetes Program criteria.[15]

- Heart disease-Rose and Blackburn's Cardiovascular Survey Methods:[16]

1. Known = existing heart disease

2. Rose $+=$ possible angina or infarction

- Hypertension-Rose and Blackburn:[16]

1. Known = hypertension diagnosed by a doctor and in treatment

2. New $=\geq 140 \mathrm{~mm} \mathrm{Hg}$ systolic pressure or $\geq 90 \mathrm{~mm} \mathrm{Hg}$ diastolic pressure, or both. A previously calibrated mercury sphygmomanometer was used, and two readings were taken.

- Cerebrovascular diseases-questions developed by the Cuban Neurology and Neurosurgery Institute to elicit selfreported morbidity and possible sequelae.

Lifestyle factors assessed were alcohol use, smoking, sedentary lifestyle, and eating pattern, defined as follows:

- Alcohol use = consumed alcoholic beverages more than five times in the last 12 months.

- Alcoholic = drinks regularly and responded positively to 3-4 CAGE test questions.[17]

- Smoker = smoking at time of survey and regularly consumed a tobacco product during at least the previous month (Cuban Consumer Research Institute criteria).[18]

- Sedentary lifestyle = primary physical activity of light intensity and ineffective additional physical activity less than four times per week, for less than 30 minutes each time (American College of Sports Medicine and FAO/WHO physical activity level criteria). $[19,20]$

- Eating pattern = 24-hour recall of food consumption, adapted by the Nutrition and Food Hygiene Institute.[21,22]

In the present study, prevalence was calculated for overweight, obesity and central adiposity, and for each of these variables in association with morbidity from diabetes, hypertension, cardiovascular and cerebrovascular diseases; and with alcohol use, smoking, sedentary lifestyle, overall eating pattern and eating daily breakfast. Confidence intervals $(95 \% \mathrm{Cl})$ were used to make the population inferences,[23] and standard $\mathrm{Cl}$ errors were obtained using Taylor series approximations. Differences in variables compared were considered significant if there was no overlap in their respective Cls; overlapping Cls indicated the difference was not significant. Results were processed using Statistical Analysis Software (SAS) version 8.02, and were presented in tables and figures.

\section{RESULTS}

Estimated prevalence of overweight and obesity in the adult population was $30.8 \%(\mathrm{Cl}: 30.1-31.5)$ and $11.8 \%(\mathrm{Cl}: 11.2-12.4)$, respectively, for a total of $42.6 \%$ with excess weight. Overweight prevalence was statistically similar in men (29.7\%; Cl: 29.1-30.3) and women (31.5\%; Cl: 31.0-32.2), but obesity prevalence was significantly different and twice as high in women $(15.4 \%$; $\mathrm{Cl}$ : 14.5-16.3) as in men (7.9\%; Cl: 7.3-8.6). Prevalence of overweight and obesity varied by age in both sexes. Overweight prevalence rose steadily in both men and women until age 39 . In women it continued to rise, peaking in middle age and then remaining at a plateau. In men, continued increase was barely perceptible until age 50-59 years, after which it declined. Obesity was more prevalent in women in all age groups and gradually increased until age 59, after which it declined. Prevalence in men varied less by age but also declined after age 59 (Figure 1).

According to the ENFRENT II data analyzed, overweight was not significantly associated with diabetes mellitus, cardiovascular diseases or cerebrovascular diseases. Obesity, however, was significantly more prevalent among diabetics and among people with a known history of heart disease. Neither overweight nor obesity was significantly associated with cerebrovascular diseases. However, both overweight and obesity were significantly more preva- 
Figure 1: Prevalence of Overweight and Obesity in Cuban Adults, by Sex and Age

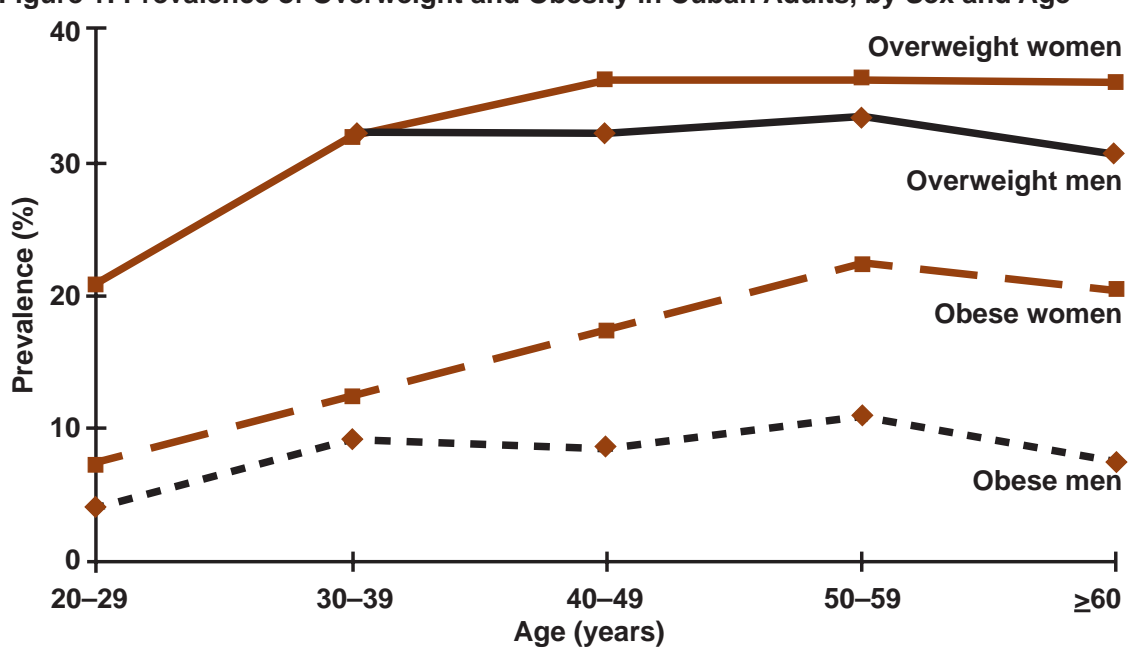

Source: Study data

Figure 2: Prevalence of Central Adiposity in Cuban Adults, by Sex and Age

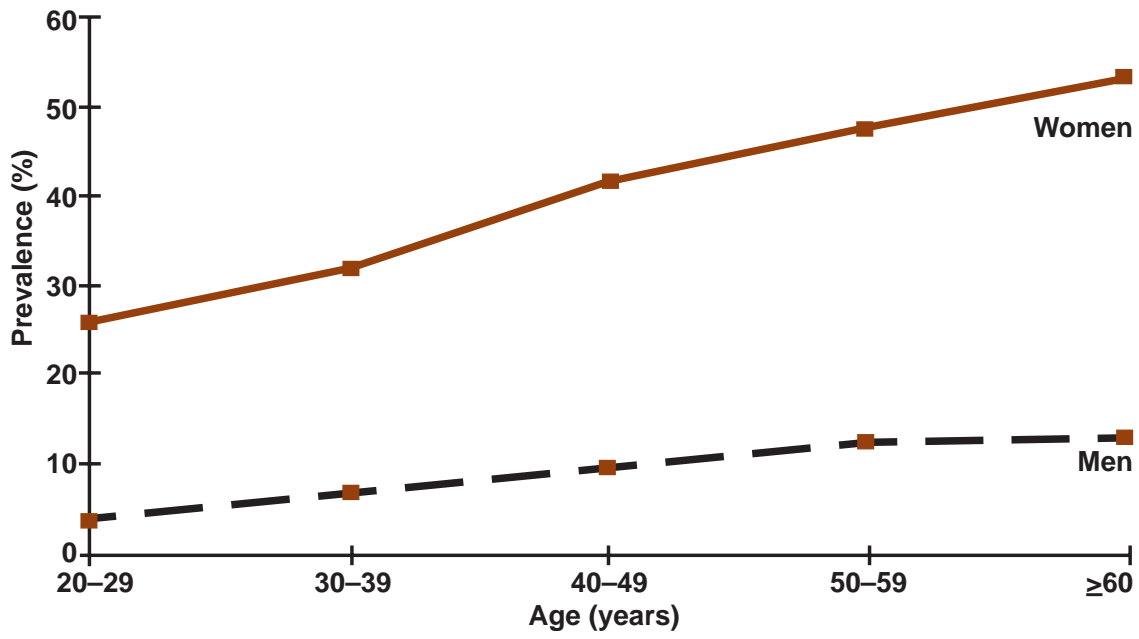

Source: Study data

Figure 3: Prevalence of Central Adiposity in Cuban Adults with Noncommunicable Chronic Diseases, by Sex

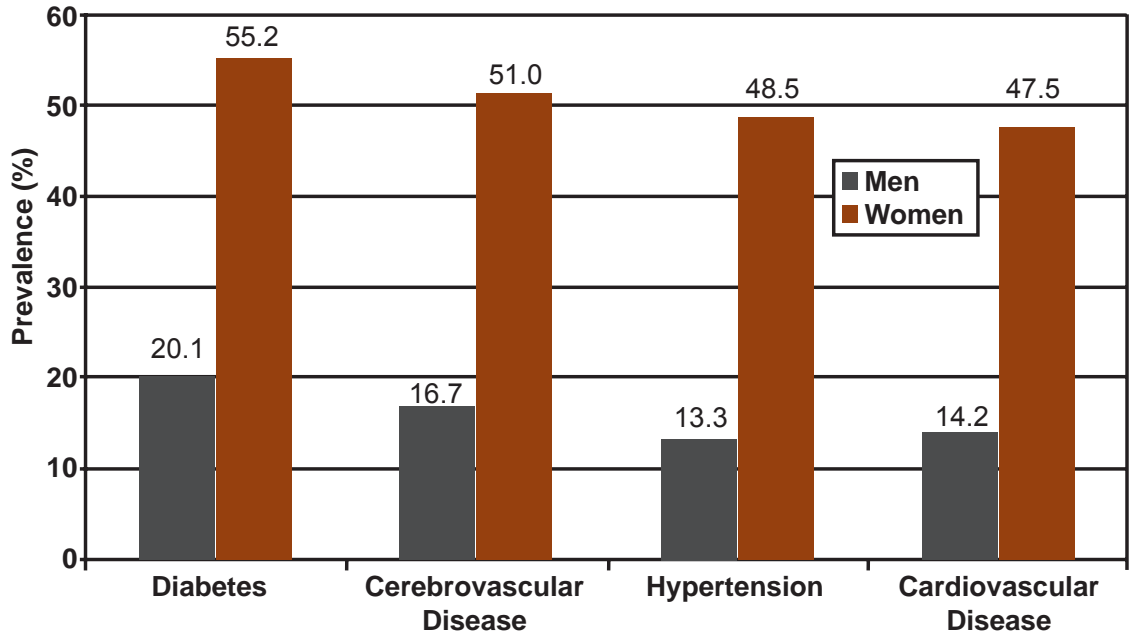

Source: Study data lent in people with known and new hypertension, compared to those with normal blood pressure (Table 1). Comorbidity with the chronic diseases analyzed was more predominant among overweight men than among overweight women but significantly more predominant in obese women than in obese men (Table 2).

With regard to the lifestyle determinants surveyed, no association was found between overweight and alcohol use, and obesity prevalence was lower among regular drinkers. Smokers were significantly less overweight and less obese than non-smokers, and a sedentary lifestyle was significantly more common in the obese (Table 3).

Analysis of eating patterns found that eating three regular meals a day was less frequent in overweight subjects $(28.5 \%$; $\mathrm{Cl}: 27.6-29.4)$ than in the general population and even lower among the obese (10.5\%; $\mathrm{Cl}$ : 9.8-11.0). Frequency of daily breakfast was the same in relation to both overweight and obesity (28.8\%; Cl: 27.9-29.6); however, overweight and obese women (31.1\%; $\mathrm{Cl}$ : 29.9-32.3 and 14.9\%; Cl: 13.9-16.0, respectively) reported skipping breakfast more frequently than overweight and obese men: $(30.2 \%$; $\mathrm{Cl}: 28.9-31.4$ and $7.9 \%$; $\mathrm{Cl}: 7.1-8.7$, respectively).

Prevalence of central adiposity varied by sex and age, was more predominant in women than in men in all groups, and also showed greater increase with age in women (Figure 2). Prevalence of diabetes mellitus, cardiovascular and cerebrovascular diseases, hypertension, obesity and overweight were significantly higher in both men and women with abdominal adiposity (Table 4), but comorbidity was nearly twice as high in women as in men. This means that women with diabetes, hypertension or cerebrovascular or cardiovascular diseases were much more likely to have a body shape showing predominance of central adiposity (Figure 3 ). Central adiposity was significantly higher in non-drinkers, non-smokers and people with a sedentary lifestyle, and was also more predominant in women with these characteristics than in men (Table 5).

\section{DISCUSSION}

One limitation of the present study is the use of data obtained in 2001; these are, however, the most recent representative data on a national scale and therefore indicative of the severity of overweight, obesity and central adiposity associated with the prevalence of chronic diseases and certain lifestyle factors in the Cuban adult population. In addition to providing important input for public health strategies and actions, this information serves as a reference for the Third National 
Survey on Risk Factors and Chronic Diseases, currently underway.

Another possible limitation is that ENFRENT II only covered urban areas; this does not invalidate use of the data to demonstrate the scope of the conditions analyzed, however, since $75.3 \%$ of the Cuban population is urban.[24]

Results of the present study indicate that obesity is a significant factor in increasing comorbidity from diabetes, hypertension and cardiovascular diseases, particularly in women. It has been estimated that $>30 \%$ of obese subjects have diabetes and that $50-80 \%$ of diabetic subjects are obese.[25,26]

Obesity is associated with increased insulin resistance that can develop into type 2 diabetes. BMI, however, explains only one-third of the total variation in insulin sensitivity, which is more strongly correlated with central obesity. As BMI increases, systolic and diastolic blood pressure also rise. Although the causes are unknown, this is probably due to elevated insulin concentrations (resulting from insulin resistance), which are conducive to renal sodium retention, higher plasma renin concentrations and an increase in catecholamine activity.[27]

Observational studies have shown a direct association between excess weight and blood pressure, underscoring the heightened risk for hypertension in obese subjects compared to non-obese individuals.[16,26]

In the past two decades, studying the regional distribution of adiposity in the body has become very important in assessing risk for chronic disease. $[2,7,10,11]$ Prevalence of comorbidity in association with central distribution of adiposity is higher than prevalence of comorbidity in association with overweight only and obesity only, indicating that abdominal fat is an independent risk factor for some chronic diseases.[6] The relationship between obesity and cardiovascular and metabolic diseases is very high when there is an accumulation of adiposity in the central region of the body, indicative of elevated lipolytic activity corresponding to a greater presence of fatty acids in the liver.[7]

The proportion of fat deposited in the abdomen increases as body shape becomes more android with age, due to decreasing height and increasing slackness of abdominal wall muscles. During adulthood, weight gain occurs in the abdominal region, emphasizing the importance of hypertrophic obesity, which is generally android.[28] This change in the adult figure may influence the positive association between age and excess abdominal adiposity, measured by waist-to-hip ratio[29] and exemplified in this study by the greater prevalence of overweight and obesity in individuals with central adiposity. At the same time, as upperbody obesity increases with morphological changes during the lifecycle, so does the burden of chronic diseases associated with this body type.[30] In this study, the greater prevalence of central obesity in women may be partly explained by the large
Table 1: Prevalence of Noncommunicable Chronic Diseases Associated with Overweight and Obesity in Cuban Adults

\begin{tabular}{|c|c|c|}
\hline Comorbidity & $\begin{array}{c}\text { Overweight } \\
\text { Prevalence \% }(95 \% \mathrm{Cl})\end{array}$ & $\begin{array}{c}\text { Obesity } \\
\text { Prevalence \% }(95 \% \mathrm{Cl})\end{array}$ \\
\hline $\begin{array}{l}\text { Diabetes Mellitus } \\
\text { Yes } \\
\text { No }\end{array}$ & $\begin{array}{l}31.9(27.6-36.1) \\
28.7(27.9-29.5)\end{array}$ & $\begin{array}{l}19.9(16.3-23.4)^{*} \\
10.7(10.2-11.3)\end{array}$ \\
\hline $\begin{array}{l}\text { Cardiovascular Diseases } \\
\text { Known } \\
\text { Rose }+ \\
\text { No }\end{array}$ & $\begin{array}{l}30.7(27.5-33.9) \\
27.0(24.2-29.9) \\
28.7(27.9-29.6)\end{array}$ & $\begin{array}{l}19.0(16.1-21.9)^{*} \\
12.7(10.3-15.2) \\
10.6(10.0-11.2)\end{array}$ \\
\hline $\begin{array}{l}\text { Cerebrovascular Disease } \\
\text { Yes } \\
\text { No }\end{array}$ & $\begin{array}{l}29.7(24.9-34.5) \\
28.7(27.9-29.5)\end{array}$ & $\begin{array}{l}11.8(8.7-14.8) \\
11.1(10.5-11.7)\end{array}$ \\
\hline $\begin{array}{l}\text { Hypertension } \\
\text { Known } \\
\text { New } \\
\text { No }\end{array}$ & $\begin{array}{l}35.0(33.4-36.7)^{\star} \\
31.3(29.2-33.3)^{*} \\
25.9(24.9-26.9)\end{array}$ & $\begin{array}{l}19.9(18.5-21.3)^{*} \\
13.4(11.9-14.9)^{*} \\
7.3(6.7-7.9)\end{array}$ \\
\hline
\end{tabular}

${ }^{*} p<0.05$

Table 2: Prevalence of Noncommunicable Chronic Diseases Associated with Obesity in Cuban Adults, by Sex

\begin{tabular}{l|l|l|} 
Comorbidity & \multicolumn{1}{c|}{$\begin{array}{c}\text { Men } \\
\text { Prevalence \% (95\% Cl) }\end{array}$} & $\begin{array}{c}\text { Women } \\
\text { Prevalence \% (95\% Cl) }\end{array}$ \\
\hline Diabetes Mellitus & $13.1(\mathrm{Cl}: 8.7-17.6)$ & $26.5(\mathrm{Cl}: 21.5-31.5)^{\star}$ \\
\hline Cardiovascular Diseases & $14.1(\mathrm{Cl}: 9.3-18.9)$ & $25.1(\mathrm{Cl}: 21.0-29.3)^{\star}$ \\
\hline Cerebrovascular Disease & $6.6(\mathrm{Cl}: 3.2-10.1)$ & $20.5(\mathrm{Cl}: 14.4-26.5)^{\star}$ \\
\hline Hypertension & $16.1(\mathrm{Cl}: 14.0-18.1)$ & $24.5(\mathrm{Cl}: 22.5-26.3)^{\star}$
\end{tabular}

${ }^{*} \mathrm{p}<0.05$

Source: Study data

Table 3: Prevalence of Overweight and Obesity Associated with Lifestyle Risk Factors in Cuban Adults

\begin{tabular}{l|l|l|} 
Risk Factor & \multicolumn{1}{|c|}{$\begin{array}{c}\text { Overweight } \\
\text { Prevalence \% (95\% Cl) }\end{array}$} & $\begin{array}{c}\text { Obesity } \\
\text { Prevalence \% (95\% Cl) }\end{array}$ \\
\hline $\begin{array}{l}\text { Alcohol Consumption } \\
\text { Current drinker }\end{array}$ & $28.9(27.7-30.2)$ & $\begin{array}{l}8.6(7.8-9.5)^{\star} \\
\text { Former drinker }\end{array}$ \\
$\begin{array}{l}\text { Non-drinker } \\
\text { Smoking }\end{array}$ & $28.7(27.2-30.1)$ & $10.7(9.6-11.8)^{*}$ \\
Yes & & $13.5(12.5-14.4)$ \\
No & $24.4(23.1-25.6)^{*}$ & $8.6(7.8-9.5)^{\star}$ \\
Sedentary Lifestyle & $31.0(30.0-31.9)$ & $12.3(11.6-13.0)$ \\
Yes & & \\
No & $29.6(28.3-30.9)$ & $12.6(11.7-13.4)^{*}$ \\
& $28.5(27.5-29.4)$ & $10.2(9.6-10.9)$
\end{tabular}

${ }^{*} p<0.05$

Source: Study data number of menopausal-aged women surveyed. Changes in the female figure are reported during menopause, including higher frequency of android body type.[28,29]

Analysis of lifestyle factors associated with weight and fat distribution in this study coincide with reports in the literature suggesting that weight gain is associated with smoking cessation, smokers tend to be thinner than non-smokers,[31] and a sedentary lifestyle is a determining environmental factor in obesity.[32] Waist-to-hip ratio has also been negatively associated with physical activity and with alcohol consumption, and positively associated with smoking.[28] In both sexes in the Cuban population, smoking and alcoholism presented less risk in association with central adi- 
Table 4: Prevalence of Noncommunicable Chronic Diseases Associated with Central Adiposity in Cuban Adults

\begin{tabular}{|c|c|}
\hline Comorbidity & $\begin{array}{c}\text { Central Adiposity } \\
\text { Prevalence \% (95\% Cl) }\end{array}$ \\
\hline $\begin{array}{l}\text { Diabetes Mellitus } \\
\text { Yes } \\
\text { No }\end{array}$ & $\begin{array}{l}44.9(40.5-49.0)^{*} \\
24.3(23.5-25.1\end{array}$ \\
\hline $\begin{array}{l}\text { Cardiovascular Diseases } \\
\text { Known } \\
\text { Rose + } \\
\text { No }\end{array}$ & $\begin{array}{l}40.2(36.4-43.9)^{*} \\
31.8(28.4-35.2)^{*} \\
23.9(23.1-24.7)\end{array}$ \\
\hline $\begin{array}{l}\text { Cerebrovascular Disease } \\
\text { Yes } \\
\text { No }\end{array}$ & $\begin{array}{l}33.9(29.2-38.6)^{*} \\
24.7(23.9-25.5)\end{array}$ \\
\hline $\begin{array}{l}\text { Hypertension } \\
\text { Known } \\
\text { New } \\
\text { No }\end{array}$ & $\begin{array}{l}34.8(33 .-36.4)^{*} \\
26.2(24.1-28.2)^{*} \\
21.3(20.4-22.3)\end{array}$ \\
\hline $\begin{array}{l}\text { Overweight } \\
\text { Yes } \\
\text { No }\end{array}$ & $\begin{array}{l}29.0(27.7-30.4)^{*} \\
23.4(22.5-24.3)\end{array}$ \\
\hline $\begin{array}{l}\text { Obesity } \\
\text { Yes } \\
\text { No }\end{array}$ & $\begin{array}{l}45.0(42.4-47.6)^{*} \\
22.5(21.7-23.3)\end{array}$ \\
\hline
\end{tabular}

posity, whereas physical activity-prevalence of a sedentary lifestyle-played a more predominant role. While the association between overweight and sedentary lifestyle in this study was not significant, prevalence of sedentary lifestyle was significantly higher in obese subjects and higher among obese women than in obese men.

Comparison of the results of the present study with an analysis of data from the First National Survey on Risk Factors and Chronic Diseases, conducted in 1995, found that overweight and
Table 5: Prevalence of Central Adiposity Associated with Lifestyle Risk Factors in Cuban Adults

\begin{tabular}{|c|c|}
\hline Risk Factor & $\begin{array}{c}\text { Central Adiposity } \\
\text { Prevalence \% }(95 \% \mathrm{Cl})\end{array}$ \\
\hline $\begin{array}{l}\text { Alcohol Consumption } \\
\text { Current Drinker } \\
\text { Former Drinker } \\
\text { Non-drinker }\end{array}$ & $\begin{array}{l}15.1(14.2-16.1)^{*} \\
25.5(23.9-27.1)^{*} \\
33.8(32.5-35.1)\end{array}$ \\
\hline $\begin{array}{l}\text { Smoking } \\
\text { Yes } \\
\text { No }\end{array}$ & $\begin{array}{l}20.3(19.1-21.6)^{\star} \\
27.4(26.5-28.4)\end{array}$ \\
\hline $\begin{array}{l}\text { Sedentary Lifestyle } \\
\text { Yes } \\
\text { No }\end{array}$ & $\begin{array}{l}30.9(29.5-32.4)^{*} \\
21.7(20.8-22.5)\end{array}$ \\
\hline
\end{tabular}

* $p<0.05$

Source: Study data

obesity (33.1\% and $42.6 \%$, respectively) increased $9.5 \%$ in approximately five years, with a greater prevalence in women. In the same period, hypertension prevalence rose $2.9 \%$ and sedentary lifestyle prevalence increased $10.3 \%,[33,34]$ a pattern similar to that observed in some developed countries and in Latin America.[25,35-40] Based on these rates of increase and prevalence, we can conclude that the problem of excess body weight and central adiposity associated with noncommunicable chronic disease is growing worse in Cuba, calling for immediate intervention. Although this may be regarded as fundamentally a public health problem, a multi-sector strategy is needed to develop comprehensive food and nutrition policies and programs aimed at halting these trends.[41] Encouraging healthy eating patterns and regular physical activity should be prioritized, particularly among children, since many of the risk factors observed in adults can be detected in childhood and, if modified, can change the course of chronic diseases.[42] Given the greater prevalence of overweight and obesity found in women, strategies should be developed from a gender perspective. -1 -

\section{REFERENCES}

1. World Health Organization. Obesity and overweight. Facts about overweight and obesity [monograph on the Internet]. Fact sheet No. 311 September 2006. [cited 2009 Jan 20]. Available from: http://www.who.int/mediacentre/factsheets/ fs311/en/index.html

2. Flegal KM, Graubard BI, Williamson DF, Gail MH Cause-specific excess deaths associated with underweight, overweight, and obesity. JAMA 2007 Nov 7:298(17):2028-37.

3. State-Specific Incidence of Diabetes Among Adults - Participating States, 1995-1997 and 2005-2007. MMWR Wkly Rep. 2008 Oct 31;57(43):1169-73.

4. Ervin RB. Prevalence of metabolic syndrome among adults 20 years of age and over, by sex age, race and ethnicity, and body mass index United States, 2003-2006. Natl Health Stat Report. 2009 May 5;(13):1-7.

5. National Institutes of Health (US). Statistic related to overweight and obesity. Weight-control Information Network. US Department of Health and Human Services, CDC; 2003 Jul. NIH Publication No::03-4158

6. Reis JP, Macera CA, Araneta MR, Lindsay SP, Marshall SJ, Wingard DL. Comparison of overall obesity and body fat distribution in predicting risk of mortality. Obesity (Silver Spring). 2009 Jun;17(6):1232-39. Epub 2009 Feb 5.
7. Seidell JC. Relationship of total and regional body composition to morbidity and mortality. In: Roche AF, Heymsfield SB, Lohman TG, editors. Human body composition. Illinois: Human Kinetics; 1996. p. 345-53

8. Seidell JC, Bakx JC, De Boer E, Deurenberg P, Hautvast JG. Fat distribution of overweight person in relation to morbidity and subjective health. Int J Obes. 1985;9(5):363-74.

9. Vague J. The degree of masculine differentiation of obesities: a factor determining predisposition to diabetes, atherosclerosis, gout and uric calculous disease. Am J Clin Nutr. 1956 JanFeb;4(1):20-34.

10. Donahue RP, Abbott RD, Bloom E, Reed DM, Yano K. Central obesity and coronary heart disease in men. Lancet. 1987 Nov 21;2(8569):1215.

11. Larsson B, Svärsudd K, Welin L, Wilheumsen L, Björntorp P, Tibblin G. Abdominal adipose tissue distribution, obesity, and cardiovascular disease and death: 13 year follow-up of participants in the study of men born in 1913. Br Med J (Clin Res Ed). 1984 May 12:288(6428):1401-4.

12. National Hygiene and Epidemiology Institute (CU). Resumen de los Resultados de la Segunda Encuesta Nacional sobre Factores de Riesgo y Enfermedades no Transmisibles. Havana; 2002.

13. Cañizares M, Barroso I, Alfonso A, García R. Estimaciones usadas en diseños muestrales complejos: aplicaciones en la encuesta de salud cubana del año 2001. Rev Panam Salud Publica. 2004;15(3):176-84.

14. Physical status. The uses and interpretation of anthropometric. Report of an expert committee WHO Technical Report Series No. 854. WHO; 1995.

15. WHO Diabetes Programme. Geneva: WHO; 1999.

16. The sixth report of the Joint National Committee on prevention, detection, evaluation and treatment of high blood pressure. Arch Intern Med. 1997 Nov 24;157(21):2413-46.

17. Ewing JA. Detecting Alcoholism: The CAGE Questionnaire. JAMA.1984 Oct 12;252(14):1905-7.

18. Cuban Consumer Research Institute (ICIODI). Encuesta Nacional de Tabaquismo 1989. Havana; 1990.

19. American College of Sports Medicine. Experts release new recommendations to fight America's epidemic of physical inactivity. News Release. 1993;29.

20. Necesidades de energía y proteínas. Informe de una reunión consultiva conjunta FAO/OMS/ONU de expertos. WHO Technical Report Series No. 724. Geneva: WHO; 1985.

21. Madrigal $\mathrm{H}$, Martínez $\mathrm{H}$, Marques-Lopes I. Valoración de la ingesta dietética. In: Martínez JA, Astiasarán I, Madrigal H, editors. Alimentación y 
salud pública. Madrid: McGraw Hill Interamericana; 2002. p. 39-51.

22. Rodríguez A, Jiménez S. Procesamiento de la información de las encuestas de consumo de alimentos. In: Martínez JA, Astiasarán I, Madrigal $\mathrm{H}$, editors. Alimentación y salud pública. Madrid: McGraw Hill Interamericana; 2002. p. 245-55.

23. Sarría M, Silva LC. Las pruebas de significación estadística en tres revistas biomédicas: una revisión crítica. Rev Panam Salud Pública. 2004;15(5):300-6.

24. National Statistics Bureau (CU). Estadísticas se leccionadas. Cuba 2007. Havana; 2008.

25. WHO Consultation on obesity: preventing and managing the global epidemic. Geneva: WHO; 1998

26. Basterra-Gortari FJ, Bes-Rastrollo M, SeguíGómez M, Forga L, Martínez JA, MartínezGonzález MA. Tendencias de la obesidad, diabetes mellitus, hipertensión e hipercolester olemia en España, 1997-2003. Med Clin (Barc) 2007;129(11):405-8.

27. Cabrerizo L, Rubio MA, Ballesteros MD, Moreno C. Complicaciones asociadas a la obesidad. Rev Española Nutr Comunitaria. 2008:14(3):156-62.

28. Kaye SA, Folson AR, Prieneas RJ, Potter JD, Gapstur M. The association of body fat distribution with lifestyle and reproductive factor in a population study of postmenopausal women. Int J Obes. 1990 Jul;14(7):583-91.

29. Lanska DJ, Lanska MJ, Hartz AJ, Rimm AA. Fac tors influencing anatomic location of fat tissue in 52953 women. Int J Obes. 1985;9(1):29-38.

30. Scarcella C, Després JP. Tratamiento de la obes idad: necesidad de centrar la atención en los pacientes de alto riesgo caracterizados por la obesidad abdominal. Cad Saude Publica. 2003;19 Suppl 1:S7-19

31. Eisenberg D, Quinn BC. Estimating the effect of smoking cessation on weight gain: an instrumental variable approach. Health Serv Res. 2006 Dec;41(6):2255-66.

32. Prevención de enfermedades crónicas: una inversión vital. Panorama general. Geneva: WHO; 2005.
33. Jiménez SM, Díaz ME, Barroso I, Bonet $M$, Cabrera A, Wong I. Estado nutricional de la población cubana adulta. Rev Española Nutr Comunitaria. 2005;11:18-28.

34. National Hygiene and Epidemiology Institute (CU). Informe sobre resultados de la Primera Encuesta Nacional sobre Factores de Riesgo. Havana; 1996.

35. Branca F, Nikogosian $\mathrm{H}$, Lobstein T, editors. The Challenge of Obesity in the WHO European Region and the Strategies for Response. Summary [monograph on the Internet]. Geneva: WHO; 2007 [cited 2009 Mar 12]. Available from: http:// www.euro.who.int/document/e89858.pdf

36. Discurso del doctor Ricardo Uauy al recibir el premio Horwitz de liderazgo en salud en las Américas. Rev Chil Nutr [serial on the Internet]. 2006 Apr [cited 2009 Apr 24];33(1):[about 3 p.]. Available from: http://www.scielo.cl/ scielo.php?script=sci_arttext $\&$ pid=S071775182006000100011\&lng=es

37. Ibáñez I. El Problema de la Obesidad en América Latina. Rev Chilena Cirugía. 2007;59(6):399-400.

38. Awad Faray W. III Congreso IFSO Latinoamericano en Chile. La obesidad, ¿un problema sin solución? Rev. Chilena de Cirugía. 2008 Jun;60(3):181-2.

39. Basham P, Luik J. Is the obesity epidemic exaggerated? Yes. BMJ. 2008 Feb 2;336(7638):245.

40. Christakis NA, Fowler JH. The spread of obesity in a large social network over 32 years. $N$ Engl J Med. 2007 Jul 26;357(4):370-9.

41. Lobo F. Políticas públicas para la promoción de la alimentación saludable y la prevención de la obesidad. Rev Española Salud Pública [serial on the Internet]. 2007 Oct [cited 2009 Jul 5]; 81(5):[about 4 p.]. Available from: http://www.scielosp.org/ scielo.php?script=sci_arttext\&pid=S1135$57272007000500001 \&$ Ing $=$ en.doi: $10.1590 /$ S1135-57272007000500001.

42. Longo E. Guías alimentarias para la población infantil. Rev Soc Argentina Nutr. 2006;7:48-50.

\section{THE AUTHORS}

María Elena Díaz Sánchez (Corresponding Author: maryelen@infomed.sld.cu), anthropologist. Full professor, Nutrition and Food Hygiene Institute (INHA), Havana, Cuba.

Santa Jiménez Acosta, nutritionist. Full professor, Nutrition and Food Hygiene Institute (INHA), Havana, Cuba.

René Guillermo García Roche, biostatistician. Associate professor and adjunct researcher, National Institute of Hygiene, Epidemiology and Microbiology (INHEM), Havana, Cuba.

Mariano Bonet Gorbea, epidemiologist. Director, associate professor and associate researcher, National Institute of Hygiene, Epidemiology and Microbiology (INHEM), Havana, Cuba.

Iraida Wong Ordóñez, anthropometry technician. Associate technical instructor, Nutrition and Food Hygiene Institute (INHA), Havana, Cuba.

Submitted: May 12, 2009

Approved for publication: September 11, 2009 